\author{
Федоренко Вікторія Павлівна, \\ Заслужений діяч мистецтв Украӥни, \\ викладач кафедри тележурналістики \\ та майстерності актора, \\ Київський національний університет \\ культури і мистеитв, \\ вул. С. Коновальия,36, Київ, Україна, 01133, \\ https://orcid.org/0000-0003-1205-3831 \\ victoriaf@ukr.net
}

\title{
КІНЕМАТОГРАФІЧНЕ МИСЛЕННЯ ЯК ФЕНОМЕН ПЦДСІДОМОГО В МИСТЕЦТВІ
}

У статті висвітлюється специфіка ідей А. Бергсона щодо феномену підсвідомого в кіномистецтві, які тримаються на теорії сприйняття, концепції «кінематографічного механізму мислення» і $є$ інструментом відтворення реальності. Мета статті - дослідити можливості сприйняття реальності засобами мистецтва та кіномистецтва. Виявити, що феномен підсвідомого в кіномистецтві є значущою проблемою візуального поля. Методика дослідження базується на методі теоретичного узагальнення, мистецтвознавчому, емпіричному та філософському аналізі. Наукова новизна полягає в поглибленому розумінні феномена кінематографічного мислення як підсвідомого в мистецтві, яке грунтуються на ідеях А. Бергсона. Висновки. Визначається структурна спільність різних видів мистецтва, існування художнього тексту та художнього образу, свідомого і несвідомого, підсвідомого, художніх універсалій.

Ключові слова: кіномистецтво; кінематографічне мислення; час; простір; свідоме й несвідоме.

Федоренко Виктория Павловна, заслуженьй деятель искусств України, преподаватель кафедры тележурналистики и актерского искусства, Киевский национальный университет культуры и искусств, ул. Е. Коновальца,36, Киев, Украина

Кинематографическое мышление как феномен подсознательного в искусстве

В статье освещается специфика идей А. Бергсона относительно феномена подсознательного в киноискусстве, которые базируются на теории восприятия, концепции «кинематографического механизма мышления» и являются инструментом воспроизведения реальности. Цель статьи - исследовать возможности восприятия реальности средствами искусства и киноискусства. Обнаружить, что феномен подсознательного в киноискусстве является значимой проблемой визуального поля. Методика исследования базируется на методе теоретического обобщения, искусствоведческом, эмпирическом и философском анализе. Научная новизна заключается в углубленном понимании феномена кинематографического мышления как подсознательного в искусстве, которое основывается на идеях А. Бергсона. Выводы. Определяется структурная общность различных видов искусства, существование художественного текста и художественного образа, сознательного и бессознательного, подсознательного, художественных универсалий.

Ключевые слова: киноискусство; кинематографическое мышление; время; пространство; сознание; бессознательное.

Fedorenko Victoriia, Honored Art Worker of Ukraine, Lecturer of the Television Journalism and Actor's Skill Department, Kyiv National University of Culture and Arts, 36, Y. Konovaltsia St., Kyiv, Ukraine

Cinematographic thinking as a phenomenon of the subconscious perception in the art The article deals with the specificity of A. Bergson's ideas about the phenomenon of the subconscious in cinema, based on the theory of perception, the concept of "cinematic mechanism of thinking", and are the instrument of reality reproduction. The purpose of the article is to study the 
possibilities of perceiving reality by means of art and cinema. The study looks into the phenomenon of the subconscious in cinema to be a significant visual field problem. The methodology of the research is based on the method of theoretical generalization, art criticism, empirical and philosophical analysis. Scientific novelty consists in an in-depth understanding of the phenomenon of cinematic thinking as a subconscious art perception, based on the ideas of A. Bergson. Conclusions. The structural community of different art types, the existence of artistic text and artistic image, the conscious and unconscious, the subconscious, and art universals are determined.

Key words: cinema art; cinematic thinking; time; space; conscious and unconscious.

Вступ. У філософії, психології та мистецтвознавстві ще в XIX - на поч. XX ст. вчені аналізували такі поняття як «образ», «знак», «символ», «сенс», «свідоме», «несвідоме», «підсвідоме». Але й сьогодні вони досі залишаються недосяжними для емпіричних наукових досліджень, бо сучасне кіномистецтво, «кінематографічний характер нашого пізнання» за А. Бергсоном є складною багатошаровою реальністю. «Несвідоме структуроване подібне мові», відзначає Жак Лакан (Коновалов, 2018, с. 161). Несвідоме - це мова Іншого, не привласненого «я» (Коновалов, 2018, с. 142).

Дослідження художньої творчості завдяки засобам мистецтва проводиться в різних галузях знання: філософії та психології, феноменології та соціології, герменевтиці і семіотиці, психо-фізіології та логіці тощо. У межах герменевтики досліджуються проблеми розуміння, світогляду, інтерпретації художнього тексту в соціокультурному аспекті філософи Х.-Г. Гадамер, П. Рікер. При цьому основне поняття «несвідоме» пов'язують 3 поняттям «сенс », що $\epsilon$ інтуїтивно зрозумілим. «Сенс - сутність чого-небудь; зміст. Розумна підстава; рація. Мета, основне призначення чого-небудь» (Поцюрко, 2014, с. 124).

У структуралістських працях К. Леві-Строса, М. Фуко, Р. Барта, де було здійснено аналіз різних сфер культури і засад щодо розуміння їхньої єдності. Це дозволило виявити певні подібності у галузі художньої творчості та описати структурну спільність різних видів мистецтва, довести існування художніх універсалій. Представники феноменології М. Хайдеггер, Г. Шпет в межах філософії («принципу всіх принципів») досліджували процес трансляції інформації, образів, знання, здійснювали пошук сенсу в різних формах (Фрейд, 1995, 53-119). Наголошуючи, що свідоме та несвідоме, сенс та інші є суб'єктивними феноменами людини. Співвідношення між свідомістю і буттям, між загальним і приватним, трансцендентним та іманентним, ідеальним та чуттєвим, знаком та значенням, поняттям та ідеєю - все це різні складники філософії.

У межах психології розглядається процес здійснення «трансляції» за допомогою кінообразу від однієї людини до іншої. Процесі сприйняття певних образів, значення підсвідомого в життєдіяльності людини описано Д. Леонтьевим., К. Юнгом, 3. Фрейдом, Е. Фроммом, М. Ярошевським, А. Бодальовим, А. Бергсоном, Ж. Епштейном, С. Ейзенштейном, М. Роммом та ін.

Сутнісні питання розуміння художнього твору розглядалися в доробку М. Бахтіна, О. Потебні, Г. Гадамера, М. Хайдеггера; естетико-філософські аспекти сучасних досліджень цієї проблематики у працях А. Бичко, М. Бровка, П. Волкової, Л. Карасьова, С. Кримського, О. Лановенка, Л. Левчук, В. Личковаха, О. Коновалова, С. Овчаренко, В. Панченко, О. Петрової поглиблюють уявлення щодо проблеми смислу художнього твору (Лакан, 1964; Дьяков, 2013). I зокрема творів кіномистецтва.

Мета статті - дослідити можливості сприйняття реальності засобами мистецтва та кіномистецтва. Виявити, що феномен підсвідомого в кіномистецтві є значущою проблемою візуального поля.

Виклад основного матеріалу. Звернення до сфери художньої творчості, до аналізу феноменів образу i підсвідомого в кіномистецтві дозволяє моделювати процеси співвідношення тексту (вербального) і візуального феномену, інтеграції кіно-мови i художнього тексту та художнього образу, свідомого і несвідомого, підсвідомого. 
Погоджуємося з М. Поцюрко, що «свідомість - це вища форма психічної активності людини, що $є$ сукупністю розумових, чуттєвих, емоційних i вольових процесів, які дозволяють людині не тільки пізнавати світ, а й перетворювати його відповідно до своїх суб'єктивних життєвих цілей» (Павло Ар'є, 2018, с. 165). Т. Нагель відзначає, що свідомість має надзвичайно складну структуру та «не підлягає науковому вивченню, тому що вона не об’єктивована» (Hottois, 1999, p. 37). Протилежністю до поняття свідомості є несвідоме.

Несвідоме - це поняття, яке має дуже широкий спектр тлумачення: від автоматичних дій людини, які не відбилися в її свідомості до розуміння його як особливої сфери психічної реальності, яка здебільшого визначає життя і вчинки людей. Несвідоме не може активно створювати дійсність, воно - результат свідомої зміни. Несвідоме своїм існуванням охоплює весь світ і все у світі, включаючи й саму людину. Несвідоме, на відміну від предметності свідомості, не має просторово-часових координат. Прикладом є феномени синхронічності, телепатії, передбачення тощо.

Поняття свідомого й несвідомого віддзеркалюють те, що в людині є людське і що в людині й у світі цьому людському протистоїть, чи у позитивному, чи у негативному сенсі.

I. Кант розглядав категорії простору і часу не як базові онтологічні характеристики буття, а як інтуїції свідомості.

Основні структурні рівні свідомості - несвідоме, підсвідоме, надсвідоме розкрито у філософії 3. Фрейда. Д. Ліндорф відзначає, що у спільній праці психолога К. Юнга і фізика В. Паулі «The Interpretation of Nature and the Psyche» на початку XX ст. проводилися ідея спільності квантового світу і колективного несвідомого. Вчені обстоювали гіпотезу, що феномен синхронії, описаний К. Юнгом, має аналог в квантовій фізиці (Леруа, 2017; Lebowitz, 1993). Наприклад, методологія квантової фізики дозволяє описати нелокальність буття, його системну зв'язність тощо. Ця методологія актуальна для опису передачі інформації, бо інформація - це закодований стан певної ділянки простору і часу, який може бути відтвореним на іншій ділянці простору і часу без втрати значущих якостей. Для цього потрібно, щоб у місцях прийому та передачі була подібна структура, сумісна з переданим повідомленням. Спілкування між людьми можливо саме тому, що ми маємо багато спільного. Кіномистецтво, телебачення дозволяють здійснювати процес комунікації засобами не лінійності мислення, розширення просторових координат та свідомості.

Французький філософ, лауреат Нобелівської премії 3 літератури Анрі Бергсон визначає сутність «життя» - «тривалість», «творча еволюція» і «життєвий порив» та намагається осягнути час (Левченко, 2000, с. 83-97). Культура, за А. Бергсоном, обумовлена вільною творчістю особистості; свобода - початковий, справжній стан людини. Він доводив, що інтелект здатний створювати «абстрактні» і «загальні» поняття. Інтелект - це діяльність розуму. У зусиллі виражено рух інтелекту від одного рівня свідомості до іншого.

Відштовхуючись від всім відомого факту, що в моменти нетерпіння або очікування час «тягнеться», а в моменти поспіху - «летить», Бергсон ввів поняття «la durée» (Бергсон, 1992, с. 51159). Е. Гуссерль писав про час свідомості як якості тривалості або «поділу» (Фрейд, 1989).

Феноменологічний час неподільний: в ньому немає окремих моментів і розривів, лише невпинне розвиток, становлення, при якому минуле, сьогодення i майбутне проникають одна в одну. Осягнути його можна, лише піднявшись над світом дискретних речей: «Дух, який має реальну тривалість, відтепер буде жити інтуїтивним життям ... Замість окремих моментів, розміщених у нескінченно подільному часу, він побачить безперервну плинність неподільного реального часу» (Бергсон, 2011). У понятті «la durée» відображена ідея «потоку»; термін «потік свідомості» («stream of consciousness») приблизно в цей же час запропонував В. Джеймс. Так плинність часу перетворилася в філософське поняття, що характеризує динамізм і безперервність внутрішнього життя - життя свідомості.

У праці «Матерія і пам'ять» А. Бергсон досліджував проблему рівнів свідомості і здатності «вловити» свідомість. Пам'ять постає інтегруючим моментом свідомості, що обумовлює єдність і самототожність людини (Бергсон, 2017, с. 107-128). А. Бергсон порівнює наше сприйняття 3 процесом проходження променя 3 одного середовища до 
іншого. Для того, щоб усвідомити механізм сприйняття і виокремлення образів свідомістю треба аналізувати особливості інтелекту особистості. Інколи «сприйняття породжується під заломленням і виникає міраж» (Бергсон, 1999, с. 437).

Проблему прийому і передачі цілісних станів на рівні несвідомого описав А. Бергсон у праці «Творча еволюція», порівнюючи стани із тим, як оса наїзник безпомилковим уколом паралізує гусінь. Філософ припустив, що оса безпомилково знаходить ганглії гусені не в результаті навчання (формування навичок шляхом «проб і помилок»), а безпосередньо відчуває ганглії гусениці, засобами власної психіки. Такий механізм пізнання А. Бергсон назвав «творчою інтуїцією» і вважав, що він притаманний усім живим істотам, оскільки вони мають спільних предків. У сучасній психології поняття інтуїції має дещо інший сенс, пов'язане з виходом за межі стереотипного мислення» (Бергсон, 1999, с. 437).

А. Бергсон також присвячує главу розкриттю феномену «кінематографічного механізму мислення». Він дійшов висновку про те, що механізм пізнання має кінематографічну природу. А кінематографічний характер нашого пізнання речей залежить від калейдоскопічного характеру пристосування до них.

Калейдоскопічний характер сьогодення актуалізують ідеї постмодерністів, які відкидають поняття класичної філософії - розум, абсолют, істина, прогрес, протиріччя, дискусія тощо. Замість цих класичних категорій вони висувають поняття «деконструкція», «тіло», «сюжет», «дискурс». Постмодерністи Ж. Бодріяр, Ж. Ф. Ліотар, Ж. Дельоз, Ф. Гваттарі, М. Серра, Р. Рорті все перетворюють в «після»: постфілософія, постнаука, постмистецтво, постлітература, постісторія. Вони визначають характерні риси постмодернізму: перегляд історичного і культурного багатства і різноманіття людства, в якому постсучасна людина черпає сили і яке створює на свій розсуд. Відмова від ієрархічного характеру відмінностей: всі міфи, всі історії, всі культури, всі форми життя мають власну цінність, і тому немає ієрархії цінностей. Толерантність, скептицизм, критика будь-якої влади, оскільки вона має репресивний характер. Відмова від «важливих віх» обгрунтування Західної цивілізації. Толерантність, скептицизм і релятивізм тощо (Heidegger, 1954, p. 445-446).

Ж. Дельоз, грунтуючись на ідеях А. Бергсона відзначає наявність кінокамери як погляд всередину матерії. Це й $є$ «сприйняття, яким воно буває у матерії, яким воно розгортається від крапки, де починається дія, до крапки, куди доходить протидії дія» (Дьяков, 2013, с. 85). I відзначає, що якщо взяти ряд засобів пересування (поїзд, автомобіль, літак тощо) і ряд засобів мистецтва (графіка, фотографія, кіно), то кінокамера є узагальненим еквівалентом засобів пересування, засобом, що дозволяє вловити миттєвість. Тому, кіно це система, яка відтворює рух у залежності від довільно взятих моментів, рівновіддалених миттєвостей, зібраних так, щоби мати враження безперервності (Дьяков, 2013, с. 85).

Всесвіт у загальній теорії відносності називають «блоковою», відзначаючи єдиність простіро-часу, в якому немає, власне, часу. Для різних спостерігачів різні події будуть сприйматися як ті, що відбуваються в різному тимчасовому порядку: те, що для одних сталося раніше, для інших пізніше (порядок подій незмінний тільки в межах одного світлового конуса). Ключовим є слово «сприйняття», так як в блоковому порядку Всесвіту всі події вже задані, вони $\epsilon$, і від цього залежить наше сприйняття. У цій моделі $є$ ступінь порядку, але відсутня течія часу (як послідовності подій), немає тут і тривалості (ідея Больцмана) (Horowitz, 1996, p. 32-38).

Голографічний принцип, який із можливості дуального опису фізичних систем, поновому пропонує поглянути на час: погляд на час як на проекцію описано Е. Віттеном (Nagel, 2004) та Х. Малдасеною (Husserl, 1928, p. 151-159).

Концепції мультіверса (і циклічних всесвітів) піднімають принципове питання про глобальний час - кожний всесвіт має власний час або такий час, що є загальним для всіх.

У кіномистецтві також можемо спостерігати блочність, голографічність, наявність мультіверса подання подій під певним кутом і від певного автора (кінооператора, ведучого, режисера тощо). 
Ці феномени простежуємо в історії кінематографу в 1685 р., коли був винайдений чарівний ліхтар - камера обскура ( подібно до театру тіней в Китаї та Японії). Чарівний ліхтар - це ящик зі збільшувальною трубою і світильником всередині (один із винарів Леонардо да Вінчі).

Формування кінематографа пов'язано $з$ діяльністю в 1791 р. Фарадея та Макса Роджера. Вони намагались винайти апарат, щоб оживити рисунок. Створений прилад Фарадея мав назву фінаксітаскопом. До апарату додавався ряд послідовних картинок. Вчений Жозеф Плато займався розкладом руху на фази . Коли Фарадей одержав у руки ці праці, йому до завершення фінаксітоскопа залишалося зовсім небагато.

31839 р. феномен кіномистецтва пов'язаний із творчістю Луї Дегар та Жозе Ньєпса. Губернатор Каліфорнії Л. Стефард і фотограф Е. Мьюбрідж провели один експеримент. Леонард дуже любив коней і посперечався с Мьюбріджем на тему того, «відриває під час галопу кінь ноги чи ні». Вони придбали 60 фотокамер і розставили їх по обидва боки бігової доріжки. Навпроти них були встановлені будочки, в яких розташувалися контролюючі камери, люди. Між тими фотокамерами і будкою був натягнутий шнурок. Коли кінь переходив на галоп і опинявся на відрізку, де були встановлені камери, він зачіпав ногою нитку, після чого камера спрацьовувала і виходило зображення однієї з фаз руху коня. Це була перша спроба розкласти рух на фази.

Кінематограф фіксує динаміку епохи, оперує часом як засобом виразності, здатний передати стрімку зміну подій, не порушуючи внутрішньої логіки. Але має недолік відсутність зворотного зв'язку творця фільму і співтворців з аудиторією (Мєднікова, 2002, с. 16). За природою кінематограф є синтетичним видом мистецтва. Він, як і театр, об'єднує літературу, живопис, режисуру, акторську гру і музичний супровід (Линдорф, 2013, с. 98).

Кінематограф - інтернаціональне мистецтво; технічні засоби забезпечують художню досконалість шедеврів кіномистецтва. Цей вид мистецтва має різноманітні засоби - монтаж, зміна точки зору, кадрування, оперування планами тощо.

Кіномистецтво сьогодні є загальнолюдським надбанням світової цивілізації. 28 грудня 1885 р. в салоні «Гран-кафе» на бульварі Капуцинів (Париж) відбувся перший публічний показ «Кінематографа братів Люмерів». 3 того часу французьке кіно ніколи не було в занепаді і є одним з найвідоміших у світі, поступаючись лише Голлівуду. На початку свого розвитку французьке кіно було переважно трюковим. Важливу роль для французького кіно відіграв Ж. Мельєс, залучивши до роботи в кіно видатних драматургів, акторів та композиторів. До Першої світової війни Франція випускала близько 90 \% світової кінопродукції (Мєднікова, 2002). Таким чином, виникнення кінематографу наприкінці XIX ст. стало визначною подією в історії світового мистецтва.

У грудні 1896 р. у Києві вперше засвітився проекційний ліхтар сінематографа братів Люм’єр. Оголошення про це видовище, було розміщене в газеті «Киянин» від 13 (25) грудня 1896 р. Українці у 90-х рр. ХІХ ст. досягли значних результатів у кінематографічній справі. Історія розвитку кіно в Києві - це поява ілюзіонів (перших стаціонарних «кінотеатрів»). Особливістю дореволюційного кіно був тісний зв'язок 3 театром, бо український кінематограф екранізував здебільшого відомі п’ єси вітчизняних митців.

Україна пишається досягненнями вітчизняної Національної кіностудії художніх фільмів ім. Олександра Довженка - кіностудія, розташована в Києві. Була створена як кінопідприємство, яке здатне забезпечити процес зйомок фільмів різної постановочної складності, різних жанрів від документальних хроніки до історичних картин. У 1925 р. Всеукраїнським фото-кіноуправлінням (ВУФКУ) було оголошено конкурс на проект кінофабрики. На кіностудію ім. Олександра Довженка у 30-х р. прийшли талановиті, вже досвідчені майстри екрану: режисери - О. Довженко, А. Кордюм, П. Долина, Л. Луков, I. Кавалерідзе, Фавст Лопатинський, I. Савченко.

Світ кіномистецтва створювали оператори - Д. Демуцький, Ю. Скельчик, М. Топчій, Й. Рона, І. Шеккер, О. Панкратьєв та ін. Основою художніх українських кінотворів стала 
творчість письменників М. Бажана, О. Корнійчука, Г. Брасюка, В. Охріменко. Це одразу позначилося як на кількості, так і на якості творів, на розмаїтті жанрів.

Порівняння кінотоворчості вітчизняної та зарубіжної є свідченням того, що митець опановує, перетворює і відображає життя в художніх образах. Розвиток кінематографа радянського періоду 20-х рp. XX ст. пов'язаний з іменами С. Ейзенштейна, В. Пудовкіна, О. Довженка. Становлення українського кіномистецтва пов'язують з фільмами О. Довженка «Звенигора», «Арсенал», «Земля».

У 20-30-х pp. ХХ ст. після того як до влади прийшли більшовики було здійснено повалення системи приватного кінопідприємництва. Радянська ідеологія та влада вимагали одночасних пошуків нових форм та методів творчості для формування радянського народу, поява жанру кіноагіток.

Поява фотографії, кіно та телефільмів, відео та медіа продукції та інших візуальних творів мистецтва розкривають характер і спрямованість руху загальноестетичних процесів та водночас демонструють вірогідний варіант тенденцій розвитку Всесвіту та культури в цілому. Відзначаємо, що художня творчість та художні образи є одним із засобів трансляції культури. Кіно завжди має на меті новий спосіб осягнення світу. Таке мистецтво є джерелом створення нових відчуттів, нового погляду на світ, умовою нового радянського досвіду. Тому вітчизняне кіномистецтво поступово набувало конструктивістських ознак: звернення до несвідомого, до архетипів, до ідей радянської та комуністичної життєбудови.

Змістовним та багатогранним є феномен пострадянського кіно - це або гротескові пародії на відновлення радянських утопій, або кримінальні драми, жанр якої з часом набув популярності (Мєднікова, 2002). Це ніби ідея «звернення до колективного несвідомого»: страху (перед пограбуванням, тортурами, вбивством) чи бажання (фантастичного збагачення, подорожі до екзотичних місць, інтерпретації чуттєвого кохання тощо). У 60-х pp. XX ст. визнання здобувають фільми «Камінний хрест», «Захар Беркут» (Л. Осики), «Сон» (В. Денисенка), «Білий птах 3 чорною ознакою» (Ю. Іллєнка), «Вавилон ХX» (I. Миколайчука).

Але паралельно розвивається й інша кіностилістика, пошук нових форм та персонажів. Так, найбільш поширеними персонажами наприкінці XX ст. стають: кілер, банкір, міліціонер тощо. Спостерігаємо велике різноманіття жанрів від кінохронік до гангстерських, дитячих фільмів та телесеріалів. Прикладом телесеріалу $\epsilon$ «Роксолана» ( режисер Б. Небієрідзе), «Острів любові», режисер (О. Бійма).

У кіно наприкінці XX ст. - поч. XXI ст. відбувається формування історичної драми, яка кількісно переважає впродовж останніх років (Лозовий, 1999). Ці фільми, відзняті за традиційними канонами, але їх наповнено домислами та концепціями сучасних вітчизняних та європейських істориків. Прикладом є творчість О. Янчука фільми: «Голод -33», «Атентат - Осіннє вбивство у Мюнхені», «Нескорений», «Залізна сотня».

Висновки. Кіномистецтво візуально відтворює світ і людину у всіх іï проявах. Відтак, свідоме та несвідоме, сенс та інші категорії є суб’єктивними феноменами людини. Отже, феномен підсвідомого в кіномистецтві грунтується на теорії сприйняття, концепції «кінематографічного механізму мислення» і $\epsilon$ інструментом відтворення реальності. Засобами екранного дійства людина поринає в «життєву реальність», яка $є$ видом буття. Взаємини «людина - екран» $\epsilon$ динамічним процесом i спирається на основу кінематографічного мислення.

\section{Список використаних джерел}

1. Бергсон А. Восприятие изменения. Философия творчества. Ежегодник. Москва, 2017. C.107-128.

2. Бергсон А. Опыт о непосредственных данных сознания. Собр. соч. В. 4 т. Т. 1. Москва, 1992. 51-159.

3. Бергсон А. Творческая эволюиия. Материя и память : пер. с фр. Минск: Харвест, 1999. 1408 c. 
4. Бергсон А. Философская интуиция : доклад на философском конгрессе в Болонье 10 апреля 1911 г. / пер. И. И. Блаубер. Путь. 2011. № 4. С.144-157.

5. Дьяков А. В. Жиль Делёз. Философия различия. Москва : Белый город, 2013. 503 с.

6. Коновалов О. Є. Артхаусний кінематограф як соиіокультурний феномен : дис. ... канд. соціол. наук : 22.00.01 / Харк. нац. ун-т ім. В. Н. Каразіна. Харків, 2018. 207.

7. Лакан Ж. Семинары. Кн.11. : Четыре основные понятия психоанализа / пер. с фр. А. Черноглазова. Москва : Гнозис: Логос, 1964. 303 с.

8. Левченко Н. О. Трансформація образності в мистецтві XX cm. : автореф. дис. ... канд. філос. наук: 09.00.08 / Ін-т філософії ім. Г. С. Сковороди НАН України. Київ, 2000. 17 с.

9. Леруа Э. О некоторых основных чертах философии Бергсона. Философские науки. 2017. № 9. 83-97.

10. Линдорф Д. Юнг и Паули: встреча двух великих умов. Москва: Касталия, 2013. 282 с.

11. Мєднікова Г. С. Украӥнська $i$ зарубіжна культура XX століття. Ukrainian and foreign culture of the 20-th century. Київ : Знання, 2002. $214 \mathrm{c.}$

12. Основи художньої культури / За ред. В. О. Лозового. Харків : Основа. 1999. 320 с.

13. Павло Ар'є, драматург: нам треба вибрати, у якому світі жити URL: https://www.5.ua/interview/pavlo-arie-dramaturh-nam-treba-vybraty-u-iakomu-sviti-zhytyrosiiskomu-de-panuie-kontrol-i-konservatsiia-dumky-chy-u-ievropeiskomu-sviti-svobody103079.html?pagespeed (дата звернення: 30.11.2018).

14. Поцюрко М. Філософія. Львів : Сполом, 2014. 277 с.

15. Фрейд 3. Введение в психоаналіз / Пер. с нем. Г. В. Барышниковой. Москва: Наука, 1989, 480 с.

16. Фрейд 3. Введение в психоанализ / Пер с нем. Г. В. Барышниковой. Москва: Наука, 1995. 455 с.

17. Husserl E. Vorlesungen zur Phänomenologie des inneren Zeitbewußtseins. Hrsg. M. Heidegger. Tübingen, 1928.

18. Heidegger M. Platons Lehre von der Wahrheit. Mit einem Brief über den Humanismus. Bern: Francke, 1947. pp. 53-119.

19. Horowitz G.T., Maldacena J., Strominger Anonextremal Black Hole Microstates and UDuality. Physical Letters B. 1996. Vol. 383. Issue 2. pp.151-159.

20. Hottois G. De la Renaissance à la Postmodernité. Paris; Bruxelles,1999. No. 8., pp. 445-446.

21. Lebowitz J. L. Boltzmann's Entropy and Time's Arrow. Physics Today, 1993. 46 (9), pp. 32-38.

22. Nagel T."What is like to be a bat?" in Philosophy of Mind: A Guide and Anthology. Oxford: Oxford University Press, 2004, pp. 32-41.

23. Pauli, Wolfgang, Jung, Carl Gustav. The Interpretation of Nature and the Psyche Pantheon Books, New York,1995.

24. Witten E. Anti de Sitter space and holography Advances in Theoretical and Mathematical Physics. 1998. Vol. 2. pp. 253-291.

\section{References}

1. Bergson A. (2017). Vospriyatie izmeneniya [Perception of change]. Filosofiya tvorchestva: Ezhegodnik. Moscow, pp.107-128.

2. Bergson, A. (1992). Opyt o neposredstvennykh dannykh soznaniya [Experience about the immediate data of consciousness]. Sobranie sochinenii V. 4 t. T. 1., pp. 51-59.

3. Bergson. A. (1999). Tvorcheskaya evolyutsiya. Materiya i pamyat'[Creative Evolution. Matter and memory]. Minsk: Kharvest.

4. Bergson, A. (2011). Filosofskaya intuitsiya: doklad na filosofskom kongresse v Bolon'e 10 aprelya 1911 g. [Philosophical Intuition: Report at the Philosophical Congress in Bologna on April 10, 1911]. Put', no.4, pp.144-157.

5. D'yakov, A.V. (2013). Zhil' Delez Filosofiya razlichiya [Gilles Deleuze. The philosophy of difference]. Moskva : Belyi gorod.

6. Freid, Z. (1989). Vvedenie v psikhoanaliz [Introduction to psychoanalysis]. Moscow: Nauka. 
ISSN 2410-1176 (Print) Вісник КНУКіМ. Серія Мистецтвознавство. Вип. 39. ISSN 2616-4183 (Online)

7. Freid, Z. (1995). Vvedenie v psikhoanaliz [Introduction to psychoanalysis]. Moscow: Nauka.

8. Husserl, E. (1928). Vorlesungen zur Phänomenologie des inneren Zeitbewußtseins. Hrsg. M. Heidegger. Tübingen.

9. Horowitz G.T., Maldacena J., (1996). Strominger Anonextremal Black Hole Microstates and U-Duality. Physical Letters B. Vol. 383. Issue 2. pp.151-159.

10. Heidegger, (1954). M. Platons Lehre von der Wahrheit. Mit einem Brief über den Humanismus. Bern: Francke.

11. Hottois, G. (1999). De la Renaissance à la Postmodernité. Paris; Bruxelles, No. 8, pp. 445-446.

12. Konovalov, O.Ye. (2018). Artkhausnyi kinematohraf yak sotsiokulturnyi fenomen [Art cinema as a sociocultural phenomenon]. D.Ed. Kharkiv State University of Arts named after named after V.N. Karazin.

13. Lakan, Zh. (1964). Seminary. Kn. 11. : Chetyre osnovnye ponyatiya psikhoanaliza [Seminars Book 11. : Four basic concepts of psychoanalysis]. Moscow: Gnozis: Logos.

14. Lebowitz, J.L. (1993). Boltzmann's Entropy and Time's Arrow. Physics Today,. 46 (9), pp. 32-38.

15. Levchenko, N. (2000). O. Transformatsiya obraznosti $v$ mistetstvi XX st.: avtoreferat dysertatsii [Transformation of imagery in the art of the twentieth century: the dissertation's abstract]. D.Ed Institutes of Philosophy G.S. Skovoroda, National Academy of Sciences of Ukraine.

16. Lerua, E. (2017). O nekotorykh osnovnykh chertakh filosofii Bergsona [On some basic features of Bergson's philosophy], Filosofskie nauki, no. 9, pp. 83-97.

17. Lindorf, (2013). D. Yung i Pauli: vstrecha dvukh velikikh umov [Jung and Pauli: the meeting of two great minds]. Moscow: Kastalia.

18. Lozovyi, O.V. Osnovy khudozhnoi kultury [Fundamentals of artistic culture]. Kharkiv : Osnova.

19. Miednikova, H.S. (2002). Ukrainska i zarubizhna kultura XX stolittia [Ukrainian and foreign culture of the 20-th century]. Kyiv : Znannia.

20. Nagel, T. (2004). "What is like to be a bat?" in Philosophy of Mind: A Guide and Anthology. Oxford: Oxford University Press, pp.32-41.

21. Pavlo Arie, dramaturh: nam treba vybraty, u yakomu sviti zhyty [Pavel Arieu, playwright: we have to choose in which world to live] Available at:<https://www.5.ua/interview/pavlo-arie-dramaturh-nam-treba-vybraty-u-iakomu-sviti-zhyty-

rosiiskomu-de-panuie-kontrol-i-konservatsiia-dumky-chy-u-ievropeiskomu-sviti-svobody103079.html?pagespeed > [Accessed 30.11.2018].

22. Pauli, Wolfgang, Jung, Carl Gustav (1955). The Interpretation of Nature and the Psyche, Pantheon Books, New York.

23. Potsiurko, M. Filosofiia [Philosophy]. Lviv : Spolom

24. Witten, E.( 1998). Anti de Sitter space and holography. Advances in Theoretical and Mathematical Physics. Vol. 2. pp. 253-291.

(C) Федоренко В. П., 2018

Стаття надійшла до редакиії: 12.06.2018 